\title{
The characteristic of creativity - reaction of children with hearing impairment to an ambiguous stimulus
}

\section{Petra Potměšilová}

\begin{abstract}
Abstrakt
V posledním desetiletí se předmětem odborných diskuzí ve vyspělých státech Evropy a v Americe stávají dovednosti potřebné pro 21. století. Jedná se o nutnost reagovat na nároky, které současná společnost klade na jedince. Centrem odborných diskuzí se tak stává nejen samotné vymezení dovedností, ale také to, jak je možné tyto dovednosti rozvíjet ve výchovně-vzdělávacím procesu. Jednou z těchto dovedností je i kreativita, která se nabízí jako možná cesta rozvoje psychosociálních a kognitivních dovedností u dětí se speciálními vzdělávacími potřebami, resp. u dětí se sluchovým postižením. Sluchové postižení patří mezi závažná postižení, která mohou výrazně negativně ovlivňovat psychosociální vývoj jeho nositele. Jednou z oblastí, která bývá sluchovým postižením ovlivněna, je deficit v chápání pojmů a jejich využívání v komunikaci. V článku jsou popsány odlišnosti ve vnímání pojmů dětmi se sluchovým postižením, které byly charakterizovány prostřednictvím výtvarné úlohy a výsledky porovnány s výsledky skupiny slyšících vrstevníků. Výtvarná úloha byla vytvořena na základě dostupných odborných pramenů a předchozích výzkumů. Pro splnění cílů výzkumu, popsání př́stupu a reakce dětí se sluchovým postižením na nejednoznačný podnět, byl zvolen kvalitativní prístup. Zakotvená teorie umožnila podrobnou analýzu nového jevu. Kvalitativní výzkum je doplněn popisnou statistikou. Získané informace jsou dány do kontextu dostupných
\end{abstract}


teoretických poznatků. V článku jsou uvedena také doporučení pro praxi, která ilustrují možný rozvoj jedné dovednosti, potřebné pro 21. století.

Klíčová slova: dovednosti 21. století, sluchové postižení, výchovně-vzdělávací proces, nejednoznačný podnět, artefiletika

\begin{abstract}
In the last decade into professional discussions in the developed countries of Europe and USA are becoming the skills needed for the $21^{\text {st }}$ century. It is the need to respond to claims that contemporary society imposes on individuals. In the center of attention of expert discussions thus becomes not only the definition of skills, but also how it is possible to develop these skills in the educational process. One of these skills and creativity, which is offered as a possible way of development of psychosocial and cognitive skills of children with special educational needs, respectively of children with hearing impairments.

Hearing impairment is one of serious disabilities that may adversely affect the psychosocial development of the person. One area that is affected by hearing impairment is the deficit in understanding of the concepts and their use in communication. The article at first describes differences in perception of concepts at children with hearing impairment, which were characterized by means of visual tasks and the results were compared with the results of their hearing peers. The experimental task was created on the basis of available expert sources and previous research. To fulfill the objectives of the research, describe the approach and the reaction of children with hearing impairment to an ambiguous stimulus was used a qualitative approach. Grounded theory permits a detailed analysis of the new phenomenon. Qualitative research is complemented by descriptive statistics. The information obtained is put into the context of the available theoretical knowledge. The article also brings recommendations for practice, which illustrates development one of possible skills needed for the $21^{\text {st }}$ Century.
\end{abstract}

Key words: Skills for $21^{\text {st }}$ century, hearing impairment, education process, ambiguous stimulus, art philetics.

\title{
Introduction
}

In the developed countries of Europe and in the United States recently Experts are professionals discussing a "Skills for the $21^{\text {st }}$ Century" Neumajer (2013) states that the term refers to the stream of thought which aims to redefine the goals of education from the traditional form into a form that reflects the changing world demands at the beginning of the $21^{\text {st }}$ century. According to him, professionals identified the following 
basic and necessary skills: collaboration, knowledge building, managing oneself, solving real-world problems, the use of ICT for learning and advanced way of communication. A list of these skills is also available on the website of the organization P21 Partnership for $21^{\text {st }}$ Century Learning. (http://www.p21.org/) A group of educators from the United States of America Thoughtful Learning $21^{\text {st }}$ Century Skills are divided into three groups: learning skills, literacy skills, and life skills. Among learning skills then, inter alia, included also creativity respectively creative thinking. (http://thoughtfullearning.com/resources/ what-are-21st-century-skills) Other authors who among the ranks $21^{\text {st }}$ century skills and creativity of the White (2012).

Hearing loss is considered in both domestic (Potměšil, 2010; Potměšilová and col., 2013; Renotiérová, 2004; Vítková, 2010; Souralová, 2002; Horáková, 2012) and foreign professional literature (Sinnott ad all., 2012; Lampropoulou, 2009; Desjardin, 2006) to be one of the most serious handicaps that can influence an individual's development, depending on the type and level.

Especially from the educational point of view this disability can have a major effect on the person concerned, in particular as regards communication and thinking capacities. For this reason the situation of people with hearing impairment in society can be compared to that of foreigners, who may have a basic idea of the society where they live and even essential language competencies. And yet, despite these skills and experience they have, they are still foreigners. They are not always able to understand slight nuances in communication (specific meaning of a word, irony, humour).

One of the ways to describe the differences of perception of children with hearing impairment, and at the same time to develop their comprehension is art philetics.

\section{Hearing impairment}

The phrase hearing impairment is used as a neutral term referring to an individual with any hearing disability, which can be displayed as qualitative or quantitative limitation of the sense of hearing. The hearing defects can be further classified using various keys: time of occurrence, qualitative or quantitative limitations.

Apart from the phrase hearing impairment there are also terms deaf and the Deaf used in the above-mentioned domestic and foreign sources. The term deaf usually describes an individual with a serious or deep hearing defect that can be also labelled as deafness. From the viewpoint of hierarchy this is one of the types of hearing impairment - the most serious one. The Deaf version has appeared in the Czech Republic in connection with the emancipation of people with hearing impairment. People, who see themselves not as disabled, but rather as a cultural and language minority, prefer to be called the Deaf. 


\subsection{Characteristics of people with hearing impairment}

According to WHO (2014) it is possible to define three basic areas of impact of a hearing defect: functional, social and emotional, and economic area.

Functional impact means the effect of hearing loss on the creation of communication skills that can influence the educational possibilities. Social and emotional impact is most often reflected in the limited access to services, and exclusion from general communication, which can lead to feelings of isolation. Economic impact is seen in the societies that do not recognize an equal right to education of people with hearing defects. In such case higher unemployment is recorded among the people with this handicap.

Glickman (1993), Nikolaraizi and Hadjikakou (2006) and Kossewska (2008) have dealt with the development and creation of identity of individuals with hearing impairment. The authors comment that the people with hearing impairment can either feel as a part of the so-called "hearing culture", or they can think of themselves distinctly as the so-called "deaf cultural minority", or they can feel to be part of both. According to those specialists the individual perception depends on several fundamental factors: family environment, experience with educational process, chosen communication strategy and also type and seriousness of the defect.

Following our own experience we can confirm the above-mentioned findings. At the same time we can state the identity of individuals with hearing impairment can change throughout their lives depending on the factors.

Potměšil (1999, p. 36) mentions that major influence of the hearing impairment can be seen in the social-cognitive area, including: impulsive behaviour, lack of self-respect, empathy development deficiencies, inability to describe current mental condition and explain feelings, limited understanding of some pro-social terms, simplified or even blackand-white concept of personal traits, and difficulties in the field of interpersonal relations.

Vymlátilová (2006, p. 89) wrote that people with this defect are often spoken of as rigid, socially immature, infantile, impulsive, egocentric and touchy. However, the same author adds that we need to avoid generalisation and focus on individual abilities of the person concerned.

\subsection{Specifics of intellect and thinking of individuals with hearing impairment}

The process of establishing concept of terms is different for children with and without hearing impairment. This is a rather complex issue that has not been examined sufficiently in the Czech environment yet. Professional publications include just a little relevant information (Zicha, 1981; Vágnerová, 1993, 2012; Davido, 2001; Solovjev, 1997; Souralová, 2002). 
Vágnerová (1993, p. 108) says that thinking is affected by a deficit in the generalisation sign system, i. e. speech. As far as practical activities are concerned, observable at the beginning of the child's development process, which were called by Piaget (1997, pp. 45-49) the sensomotoric phase, the child with hearing impairment gains certain knowledge and realises the basic relationships. To continue to the next development phase the child needs a sufficient volume of adequate ideas and their utilisation when resolving new situations. In this second period (according to Piaget 1997, pp. 45-49, pre-term period) the child needs to deal with new situations not just by factual activity, but also indirectly, using internal mental activities: transition takes place to a higher level of the so-called symbolic thinking. The child gains basic generalisation ability. At this stage different development can be seen in the children with hearing impairment. The word "can" should be emphasised, because different development will be influenced by the level of seriousness of the defect, and by the environment where the child lives. Thinking may not be completely tied to a specific situation, but the generalisation remains at the level of Piaget's concept of symbol, which is somehow similar to the object concerned. However, generalisation on the basis of a speech sign, which is more general and conventional, remains a problem.

Solovjev' (1977) claims that the main feature of this stage or period is a symbolic game played by the child. The child is able to use various objects to imitate some specific activities. Imagination that allows one to play with a stick as a thermometer is created in the process of abstraction, through illustrative thinking. In this situation to redefine the stick to thermometer is an expression of abstraction ability. (Solovjev, 1977, p. 146) The author further mentions that with the children with hearing impairment such game can be seen only later. This is to a certain extent related to the delayed development of their abstraction activities. (Solovjev, 1977, p. 146) Solovjev has supported his claims by the research he had completed with children with hearing impairment from the ages of 6 to 7 .

Souralová (2002) deals with mental vocabulary of children with hearing impairment in relation to the reception of written text. She mentions one very important fact here: the need to install the words into a semantic network, namely using the connections between coordination, subordination and semantic fields. (Souralová, 2002, p. 11) The above-mentioned can be taken as a basic principle of work with children with hearing impairment in the field of developing terms, or thinking. As regards correlations, creating connections, the semantic fields of a term should be an obvious replacement for the things the child with hearing impairment cannot hear.

\footnotetext{
There is a number of authors dealing with the hearing impairment issue, both in Czech and foreign sources (e.g. Souralová, Horáková, Vágnerová, Potměšil, Marschack, Lampropoulou), but none of them provides a comprehensive view of the specific issue of developing the concept of terms in the case of children with hearing impairment. For this reason, to describe the above-mentioned topic sources from 1977 and 1978 were used, dealing with this issue.
} 
Sándor ${ }^{2}$ (In: Gyuláné, 1978) says that non-verbal thinking of the children with hearing impairment is at a higher level as compared to the hearing children. He defines the non-verbal thinking as a mental process that takes place at a specific level using analysis and synthesis of images. Solution of a problem is not reflected in the term, word and language fields. Where problem solving is transferred to the verbal area, the problem is defined by words and thinking uses abstract terms, not specific images.

Following the findings in the above-mentioned professional sources and results of own research (Kalendová, 1997, 2004; Potměšilová, 2009) it is possible to summarise the differences of grasping a term by children with hearing impairment into several points:

- Mental operations are more specific;

- Meaning is often related only to a specific object, not a class of phenomena (prototype is not developed enough - common and differentiating features - certain object classification - so-called prototype theory);

- Problems related to imagination.

This means that concerning children with hearing impairment we often experience the fact that they "know" a lot of words. It seems they have a vast vocabulary. From own practice we know the following sentence very well: "I know the word, I've seen it, but I can't explain it." But the words are not grasped as terms.

With children with hearing impairment we often come across one phenomenon: naming is connected to a specific matter, being closer to indexing (thing, person, effect). This is because they are taught to orientate themselves in normal life and to be able to deal with everyday situations (e.g. shopping). The point is they learn a selected skill in a specific situation or connection, and are using it in the given connection only. This means they deal with it on the basis of context, not a general concept independent on the context, which proves handling of terms within language system at a relevant abstraction level. The decentration process has not been completed well.

One of the causes of the situation is the fact that child with hearing impairment cannot hear "the important connections" that help the hearing children to fully grasp a term. Therefore one phenomenon is rather frequent: an individual with hearing defect ends up in a situation that is somehow new, unknown, confusing, and the individual tries hard to find something known and certain to be able to comprehend.

\section{Creativity and individual}

From a biological point of view creativity is influenced by the brain activity. Jamison (1997) and Gardner (1993) were among those who researched biological effects on creativity. Jamison focused on the relationship between creativity and mental defects,

2 Dtto 
specifically bipolar disorders. Gardner has dealt with the possibilities of initiation of cognitive abilities, such as learning and creativity. In relation to this issue Gardner (1999) mentions spatial type of intelligence.

Further, for example Dacey and Lennon (2000) speak of the basic factors influencing brain development. Apart from proper nutrition and social interaction they mention also less obvious conditions that can have an effect on later creativity: noise level, modulated sounds - pleasant ambient music, pastel colours in the room, or gentle movements of people taking care of the child. Lack of such stimulus can result in limited brain development and consequently to lower creativity. However, it cannot be claimed that deprivation at an early age always results in limited development of micro neurons, or weak creative abilities, yet the correlation is clear (Dacey and Lennon, 2000, p. 167).

The correlation mentioned above can be applied in the situation of a child with hearing impairment. Following the limited ability to receive audible information they can be deprived at an early age. It's been mentioned already that the impossibility to hear modulation factors influences the abilities of an individual with hearing impairment. In this context we can only sum up that hearing impairment can affect brain development and also the level of creativity.

\subsection{Art philetics}

Art philetics is a discipline with close links to art therapy. It uses similar processes as art therapy, but in the educational context. The objective of art philetics is not to treat, but to contribute to self-recognition, development of personality and positive personal traits in the educational process. It can also be used as a creativity development method.

The person who coined the term art philetics, and the spiritual father of the whole discipline is Jan Slavík (1997), who defines the art philetics approach as a special concept of art education or in the wider sense expressive education touching the field of art therapy and mainly focusing on authentic experience learning about human culture and development of emotional, social and creative aspects of human personality.

According to Slavík (1997) the term art philetics approach covers two areas of meaning: Latin ars - art and philetics - an approach that connects creative expression as a principle of artistic creation with reflection as a scientific principle.

By combining the two areas it is possible to define art philetics as an educational concept whose main principle is to connect expression play (e.g. visual art) with reflecting dialogue. The purpose of the art philetics approach is to provide people with an opportunity to reveal their own mental capabilities and limits, with a chance to find their place and role in the community of humans, to equip them with sensitivity to pain of other people, to prepare them for spiritual growth and finding the sense of life with support by human culture, especially art (Slavík, 1997). 


\section{Research}

The objective of the research was to describe the response of children with hearing impairment at the ages of 8-12 to an ambiguous stimulus in the form of a visual art task. Combination of qualitative and quantitative methodology was chosen for the research implementation.

\subsection{The issue}

Individuals with hearing impairment experience problems with understanding and practical use of some terms. Due to the hearing defect their conditions for the natural process of creation and saturation of semantic fields and term differentiation are more difficult, and consequently the conditions for functional creation of term structure are more complicated. Insufficient comprehension of terms is then reflected in thinking, which is considered to be a necessary precondition of learning, i.e. a necessary precondition of the educational process. Apart from the impact on the educational process different term structure can have an impact on everyday life. An individual with hearing impairment can fail in ordinary situations that require application of verbal intelligence. On the basis of this fact the issue of our research was formulated:

The understanding and application of term structure by children and pupils with hearing impairment is different from the understanding and application of term structure by intact children and pupils.

There are special pedagogical procedures that can help natural and functional creation of the term structure of children and pupils with hearing impairment.

\subsection{Research questions}

Based on the definition of the researched issue and its theoretical outline the following research questions were formulated:

Are children and pupils with hearing impairment able to receive ambiguous stimulus?

In what way do the children and pupils with hearing impairment receive an ambiguous stimulus?

Is the response of the children and pupils with hearing impairment to an ambiguous stimulus different from that of intact children and pupils? If yes, in what way? 


\subsection{Research population}

Table 1

Characteristics of research population

\begin{tabular}{|l|l|l|}
\hline RESEARCH & CHARACTERISTICS OF RESPONDENTS & QUANTITY \\
\hline $\begin{array}{l}\text { Collection } \\
\text { Group A }\end{array}$ & $\begin{array}{l}\text { Age 8-12 } \\
\text { Intact population } \\
\text { The Czech Republic }\end{array}$ & 70 \\
\hline $\begin{array}{l}\text { Collection } \\
\text { Group B }\end{array}$ & $\begin{array}{l}\text { Age 8-12 } \\
\text { With hearing impairment } \\
\text { The Czech Republic }\end{array}$ & 63 \\
\hline
\end{tabular}

\subsection{Description of selected aspects of the research}

The research took place in 2014. To collect the data the qualitative method of analysis of the obtained materials was used, followed by anchored theory method.

All the respondents were given the image below - ambiguous stimulus (Fig. 1), a white A4 sheet of paper, glue and crayons.

\section{Figure 1}

Ambiguous stimulus

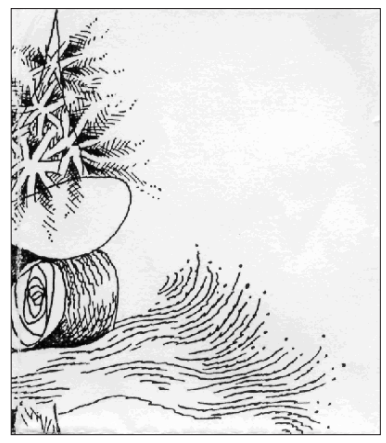

Instructions were given:

"You have received part of a picture. First of all look at it carefully, you can also rotate it. As soon as you think the picture reminds you of anything, try to complete it. Glue the part of the picture on the white paper you have received. You can modify the picture in any way you like. You can use any of the materials you have received." 
Each of the reactions to the ambiguous visual stimulus (see above) was subsequently analysed:

- Separation of adequate from inadequate reactions;

- Sorting into topical categories (identification of patterns and simple summary).

To process the data coding was used. With open coding individual responses were gradually classified, and axial coding later allowed to look for specific features - details of individual pictures. On the basis of this coding a more accurate image was created of the individual categories and differences between categories for both the groups. As an example of open coding we provide one category (Character), see Table 2; Table 3 includes the evaluated specific features for axial coding.

Table 2

Example of open coding category

\begin{tabular}{|l|l}
\hline Character & $\begin{array}{l}\text { The original motif is part of the face } \\
\text { The original motif is part of the body } \\
\text { The original motif is part of clothes } \\
\text { The original motif is part of a fantasy or fairytale character } \\
\text { The picture is a functional part of a character }\end{array}$
\end{tabular}

Table 3

Specific features for axial coding

\begin{tabular}{|l|}
\hline Overall concept \\
\hline Colour design \\
\hline Details \\
\hline Way of use of the original motif \\
\hline
\end{tabular}

Following the above-mentioned processes we moved on to formulate a theory: The characteristics of creative response of pupils with hearing impairment at the ages of 8 to 12 to an ambiguous stimulus are determined by these statements:

It can be a problem for the children and pupils with hearing impairment to respond to an ambiguous stimulus.

Where adequate response to an ambiguous stimulus appears, it is a standard reaction. In the categories into which the adequate responses are sorted there are no differences compared to the intact population.

Apart from the features typical for the age there are also features appearing in the artistic expression typical for earlier age that should not appear anymore.

The features typical for earlier age appear on pictures related to human life. 
The features corresponding to the given age appear on pictures primarily not related to human activities.

Formal work is preferred to content.

The ability to respond to an ambiguous stimulus is one of the abilities contributing to problem solving strategy. To recognise the problem is an important step, from which the very solution is derived. Only a problem that has been recognised can be solved. Definition of a problem follows recognition of the problem. When defining a term further recognition of the problem may occur. If one succeeds to recognise and subsequently define a problem, one can formulate the problem solving strategy.

When processing the results, the inadequate reactions and threshold reactions to ambiguous stimulus, where the respondents just mirrored the original motif, were classified as problematic. In a practical situation such response could go like this: the individual with hearing impairment does not notice the stimulus and starts talking about something else / solving another problem. As regards the threshold reactions the stimulus is repeated, but not developed and followed. From the viewpoint of further development of thinking abilities this is a dysfunctional strategy. We have referred to these strategies above as defensive. This is because in practice this might at first glance look as if the individual with hearing impairment is oriented in the situation, because he/she is speaking or solving. But in reality the response is not related to the stimulus, and the person is doing something else.

In the case of adequate reactions we can see differences related to the impact of hearing impairment on speech development - understanding of terms - thinking. The responses more connected to language development and human activities display properties typical for lower age. On the contrary, reactions related more to nature, without a direct link to human activities, are at an adequate level. We can see a parallel to this phenomenon also in the differences between verbal and non-verbal intelligence of children and pupils with hearing impairment, as stated for example by Šedivá (2006) and Vágnerová (1999).

The newly formulated theory was complemented with descriptive statistics. To give the reader a basic idea, we provide a chart with comparison of occurrence of individual categories - responses to an ambiguous stimulus of intact children (Group A) and children with hearing impairment (Group B). 
Chart 1

Comparison of frequency of reactions

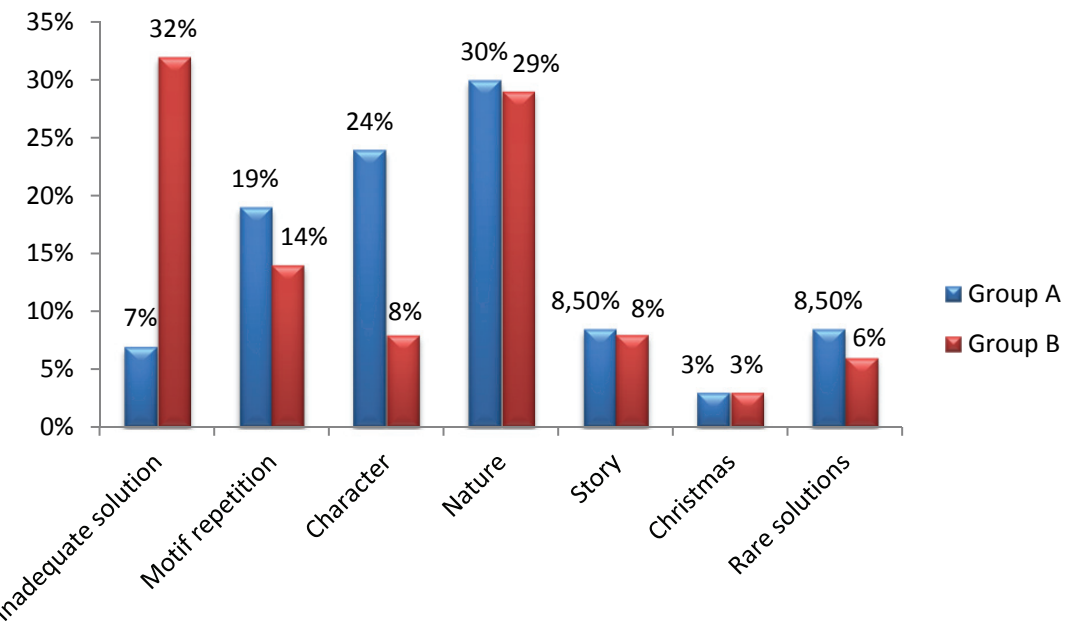

\subsection{Validation of research questions}

The research had three basic stages in logical sequence. During the first and second stage we collected information on the researched issue, and created the overall picture in relation to the available professional sources. During the third, pivotal stage of the research we narrowed the issue onto children and pupils with hearing impairment at the ages of 8 to 12. The topic of creation and perception of terms in this population is a very complex one, as yet not thoroughly explored. Most educational specialists dealing with the process of educating children and pupils with hearing impairment are aware that this group processes verbal terms differently, but there is no functional educational procedure introduced to ensure that individuals with hearing impairment are able to comprehend words/terms in Czech language within the full scale of their meanings.

In the third part of our research we described in detail the specifics of responses of respondents to ambiguous stimulus (Group B), and compared the reactions with those of the respondents without hearing impairment (Group A). Following the description we are able to gradually answer the formulated research questions:

Are children and pupils with hearing impairment able to receive ambiguous stimulus?

Almost half of the pupils with hearing impairment is able to receive ambiguous stimulus. However, this ability was not recorded with all the children and pupils. We 
consider this finding an important one with regards to further research and formulation of practical recommendations.

In what way do the children and pupils with hearing impairment receive an ambiguous stimulus?

Referring to the results: the children and pupils with hearing impairment approach an ambiguous stimulus in three ways:

They don't understand the problem, they ignore it and create without links to the stimulus.

They don't understand the stimulus, but they notice it and mirror-reflect it.

They understand the problem, they assign it some meaning and process it creatively.

The types of responses of the children and pupils with hearing impairment to ambiguous stimulus were identical with those of intact children and pupils.

Is the response of the children and pupils with hearing impairment to ambiguous stimulus different from that of intact children and pupils? If yes, in what way?

The results have shown there are differences. We mentioned earlier that the types are identical, but their frequency is considerably different. The frequency of inadequate reactions to the original stimulus is higher among the children and pupils with hearing impairment (meaning response reflecting the fact that the ambiguous stimulus was not taken in). Another major difference is the way of processing the response. As regards the children and pupils with hearing impairment, we see more often the emphasis on formal aspect of the problem solving. The paintings are coloured, full of details, with overall composition. The intact children and pupils concentrate more on the execution itself. Attention to colours, details and overall composition is not that frequent.

Therefore in general we can state that differences exist between the children and pupils with hearing impairment and intact children related to the way they respond to an ambiguous stimulus. The fundamental difference is not the type, but frequency and character of the reactions.

On the basis of the results of the research, and particularly from the detailed analysis of the character of reactions of the children and pupils with hearing impairment to an ambiguous stimulus we have compiled the practical recommendations below.

\subsection{Practical recommendations}

Art philetics is an educational discipline that allows creation of functional combination of self-expression and space for feedback. As a means of this combination techniques are used linked to creative arts. For this reason the art philetics is a suitable method of work with the children and pupils with special needs.

The children and pupils with hearing impairment could be led via art philetics to higher sensitivity to ambiguous stimulus, and to better understanding of the principle 
of semantic field creation. Apart from the development of this important skill most of the techniques have another meaning in real life as well. As an example we can mention the Reconstruction method, which we used as the basic method in our research. This method has three possible uses in practice:

- Fantasy development

- Communication skills development

- Problem solving strategies

Table 4

Example of specific technique

\begin{tabular}{l|l|}
$\begin{array}{l}\text { Sort the pictures (joy, sadness, fear, danger) } \\
\text { Time: Approx. } 45 \text { min }\end{array}$ & $\begin{array}{l}\text { Practical observations: } \\
\text { We focus the discussion on the topic of what } \\
\text { Aids: A set of art therapy materials, pictures } \\
\text { has led whom to matching a particular picture } \\
\text { Assignment: We give the children various pic- } \\
\text { tures and ask them to sort them according to } \\
\begin{array}{l}\text { what they mean to the children. Then we ask } \\
\text { the children to communicate their feelings. }\end{array}\end{array}$ \\
\hline
\end{tabular}

\section{Conclusion}

Hearing insufficiency is the type of disability that can have a major influence over the quality of life of the person concerned, who consequently cannot use all the functions of unintentional learning, depending on the character of the defect. This fact means that the entire educational process can be affected, as well as personality development. Insufficient possibilities of unintentional learning have a major negative impact on the development of communication competencies of children with hearing impairment. Another impact can be traced in the field of emotional experience related to both the person him/herself and empathy as an important function within social competencies of an individual. But this will be the subject of the next research.

Following the theoretical starting points for the issue and the research results it is possible to conclude that the children and pupils with hearing impairment compared to the intact children have more problems responding to an ambiguous stimulus. In the event of adequate response this displays higher level of detail (elaboration and fluency) compared to the intact children of the same age. Where human character appears in the pictures, the painting usually displays features typical for earlier development stages.

The cause of these characteristics can be found in the seriousness of the hearing defect and in the impact the defect has on the person concerned, namely from the viewpoint of education and learning in childhood. 
There is a close link between the perception of ambiguous stimulus and the level of communication competencies, and their influence on the educational process. As the functional level of perception of an ambiguous stimulus is lower with the children and pupils with hearing impairment as compared to their intact peers, from the viewpoint of special pedagogy we consider it necessary to look for possible ways of developing the aforementioned competencies, with positive impact on the overall learning process in its essential segments as a basic precondition of upbringing and education.

With reference to other abilities and skills of the children and pupils with hearing impairment the suitable way seems to be the development of creativity of this target group using fine arts, i.e. targeted inclusion of art philetics into the educational process of the children and pupils with hearing impairment. Arte philetics can become a functional way to develop creativity in children with hearing impairment, which will have an impact on the development of psychosocial skills which are needed for the $21^{\text {st }}$ century.

\section{References}

Dacey, J. S., Lennon, K. H., (2000). Kreativita. Praha: Grada.

Davido, R., (2001). Kresba jako nástroj poznání dítěte. Praha: Portál.

Desjardin, J. L., (2006). Family Empowerment: Supporting Language Development in Young Children Who Are Deaf or Hard of Hearing. Volta Review, roč. 106, č. 3, s. 275-298.

Gardner, H., (1993). Creating minds: An anatomy of creativity seen through the lives of Freud, Einstein, Picasso, Stavinksy, Eliot, Gahem and Gandhi. New York: Basic Book.

Gardner, H., (1993). Frames of Mind. The Theory of Multiple Intelligences. New York: Baic Book.

Guilford, J. P., (1967). The Nature of Human Intelligence. New York: McGraw-Hill Education.

Gyuláné, I., a kol., (1978). Špeciálno pedgogická psychológia. Bratislava: Slov. ped. nakl.

Hdjikakou, K., (2011). Deaf identity construction: a case study, Annales Universitatis Paedagogicae Cracoviensis, Studia Psychologica, IV, p. 22-33.

Horáková, R., (2012). Sluchové postižení: úvod do surdopedie. Praha: Portál.

Jamison, K. R., (1995). Manic-depressive illness and creativity. Scientific American, p. 62-67. [online] [cit.: 30.9.2014] received from: http://www.mmu.k12.vt.us/teachers/kefferm/humanbio/nervous/articles/1995\%20feb\%20depression\%20and\%20creativity.pdf

Kalendová, P., (1997). Symbolické a znakové vyjadřování sluchově postižených dětí ve výtvarné výchově. Diplomová práce. Praha: PedF UK.

Kalendová, P., (2004). Znak a symbol jako výrazové a komunikační elementy ve výtvarné výchově sluchově postižených. Disertační práce. Praha: PedF UK.

Kossewska, J., (2008). Personal identity in deaf adolescents. Psychological and Pedagogical Survey, 2, p. 67-75.

Lampropoulou, V., (2009). The education of Deaf Children in Greece. In Moores, D. F., Miller, M. S. (eds.), Deaf People Around the World: Educational and Social Perspectives. Washington D. C: Gallaudet University Press.

Neumajer, O. (2013). Výukové aktivity pro rozvoj dovedností 21. století. Řízení školy, 2, s. 14-16.

Piaget, J. \& Inhelderová, B., (1997). Psychologie dítěte. Praha: Portál.

Potměšil, M., (1999). Úvodní stati k výchově a vzdělávání sluchově postižených. Praha: Fortuna.

Potměšil, M., (2003). Čtení k surdopedii. Olomouc: UP. 
Potměšilová, P. (2010). Úprava testu WISC-IIIUK pro potřeby vyšetření dětí se sluchovým postižením. In Potměšil, M. a kol. Psychosociální aspekty sluchového postižení. Brno: MU, pp. 133-155.

Renotiérová, M. a kol., (2004). Speciální pedagogika. 2. vyd. Olomouc: UP.

Sinnott, Ch., Looney, D. \& Martin, S. (2012). Social Work with Students Who Are Deaf or Hard of Hearing. School Social Work Journal, 36, 2, pp. 1-14.

Slavík, J., (1997). Od výrazu k dialogu ve výchově - Artefiletika. Habilitační práce. Praha: Karolinum.

Slavík, J., (2001). Umění zážitku, zážitek umění. Teorie a praxe artefiletiky 1. díl. Praha: PedF UK.

Slavík, J., Chrz, V. \& Štech, S. (2013). Tvorba jako způsob poznávání. Praha: Karolinum.

Slavík, J., \& Wawrosz, P., (2004). Umění zážitku, zážitek umění. Teorie a praxe artefiletiky. 2. díl. Praha: PedF UK.

Solovjev, I. M. a kol., (1977). Psychologie neslyšících dětí. Praha: SPN.

Souralová, E., (2002). Čtení neslyšících. Olomouc: UP.

Stančák, A., (1982). Klinická psychodiagnostika. Bratislava: Psychod. a did. testy.

Šedivá, Z., (2006). Psychologie sluchově postižených ve školní praxi. Praha: Septima.

Vágnerová, M., (1993). Variabilita a patopsychologie vývoje. Praha: Karolinum.

Vágnerová, M., (2012). Patopsychologie pro pomáhající profese. Praha: Portál.

Vymlátilová, E., (2006). Sluchově postižené dítě. In Říčan, P. a kol. Dětská klinická psychologie. 4. přep. a dopl. vyd. Praha: Grada.

White, N. (2012). Assessing $21^{\text {st }}$ Century Skills. [online cit. 2015-05-05] received from: http://d20innovation.d20blogs.org/2012/11/03/assessing-21st-century-skills/

Zicha, Z., (1981). Úvod do speciální výtvarné výchovy. Praha: PedF UK.

This article was supported by a grant:CMTF_2015_010

\section{Contact:}

PhDr. Mgr. Petra Potměšilová, Ph.D.

Department of Christian Education

StS. Cyril and Methodius Faculty of Theology

Palacký University in Olomouc

Univerzitní 22,

77111 Olomouc

Czech Republic

E-mail: petra.potmesilova@upol.cz 